\title{
Recycling of Rubber Wastes as Fuel and Its Additives
}

\author{
Ahmed Akbas (D) and Nor Yuliana Yuhana * \\ Department of Chemical \& Process Engineering, Faculty of Engineering \& Built Environment, \\ Universiti Kebangsaan Malaysia, Bangi 43600, Selangor, Malaysia; p103691@siswa.ukm.edu.my or \\ ahmadrooy@yahoo.com \\ * Correspondence: yuliana@ukm.edu.my
}

\begin{abstract}
Economic, social, and urban developments generally require improvements in the transportation sector, which includes automobiles such as trucks, buses, trailers, airplanes, and even bicycles. All these vehicles use rubber tires. After consumption, these tires become waste, leading to enlarged landfill areas for used tires and implying additional harm to the environment. This review summarizes the growth of rubber recycling application and the sustainability of using waste rubber in the construction field. Furthermore, we provide methods to convert rubber waste to fuel or fuel additives by using tire-derived fuel and concentrate to pyrolysis, which are environmentally friendly and efficient ways. The related parameters such as temperature, pressure, and feedstock composition were studied. Most research papers observed that $500{ }^{\circ} \mathrm{C}$ is the optimal temperature at atmospheric pressure in the presence of a specific type of catalyst to improve pyrolysis rate, oil yield, and quality.
\end{abstract}

Keywords: rubber waste; fuel; fuel additives; sustainability; pyrolysis; recycling

Citation: Akbas, A.; Yuhana, N.Y. Recycling of Rubber Wastes as Fuel and Its Additives. Recycling 2021, 6, 78. https://doi.org/10.3390/ recycling 6040078

Academic Editor:

Marc Marín-Genescà

Received: 30 July 2021

Accepted: 18 November 2021

Published: 1 December 2021

Publisher's Note: MDPI stays neutral with regard to jurisdictional claims in published maps and institutional affiliations.

Copyright: (c) 2021 by the authors. Licensee MDPI, Basel, Switzerland. This article is an open access article distributed under the terms and conditions of the Creative Commons Attribution (CC BY) license (https:// creativecommons.org/licenses/by/ $4.0 /)$.

\section{Introduction}

\subsection{Ecosystem Limitation}

Ecosystem services are the advantages people receive from nature. Human survival and well-being depend on these services. Thus, humans must provide the protection and best management to ecosystems [1,2]. The contamination of seas by polymer products is expected to cause a yearly loss of $1-5 \%$ in ecosystem services, resulting in financial losses of roughly USD 2.5 billion per year [3,4]. Plastic from $(<1 \mathrm{~m}$ to less than $1 \mu \mathrm{m})$ have the ability to interact with aquatic creatures from all trophic levels and thus have various harmful impacts [5-7].

Extensive and rising quantities of polymer pollution exist in the aquatic environment, which we henceforth refer to as "marine plastic" [8]. Approximately 4.8-12.7 million metric tons of plastic entered the oceans water from land-based sources in 2010 alone, and the flux of plastics to the seas is forecast to increase by an order of level within the next decade [9]. Over time, these plastics may disintegrate into little parts, called "microplastics" $(0.1 \mu \mathrm{m}-$ $5 \mathrm{~mm}$ ), whose massive majority is expected to persist in the environment in several forms over geological periods [10].

\subsection{Rubber-Application Growth}

As we mentioned previously, there is a current global concern about the environment, with fuel emission consequences to the atmosphere on one hand, and how to gain advantage from other items which cause different types of pollution on other hand.

Rubber is an example of an elastomer class of polymer with the ability to return to its original shape after being stretched or deformed, called natural rubber [11]. Figure 1 shows the natural rubber structure. 


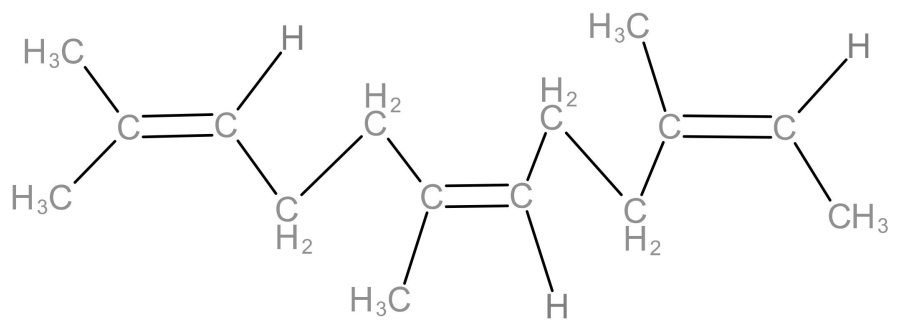

Figure 1. Natural rubber structure.

Conversely, synthetic rubber (also called commercially styrene-butadiene rubber $(\mathrm{SBR}))$, is a copolymer of 1,3-butadiene and styrene mixed in a 3:1 ratio [12]. Rubber has a deep effect on the environment and takes multiple forms. We use it in daily activities such as protective gloves, electrical instruments, and plastics, and one of the most crucial is tires. Figures 2 and 3 shows the consumption of natural and synthetic rubber worldwide (2017-2020).

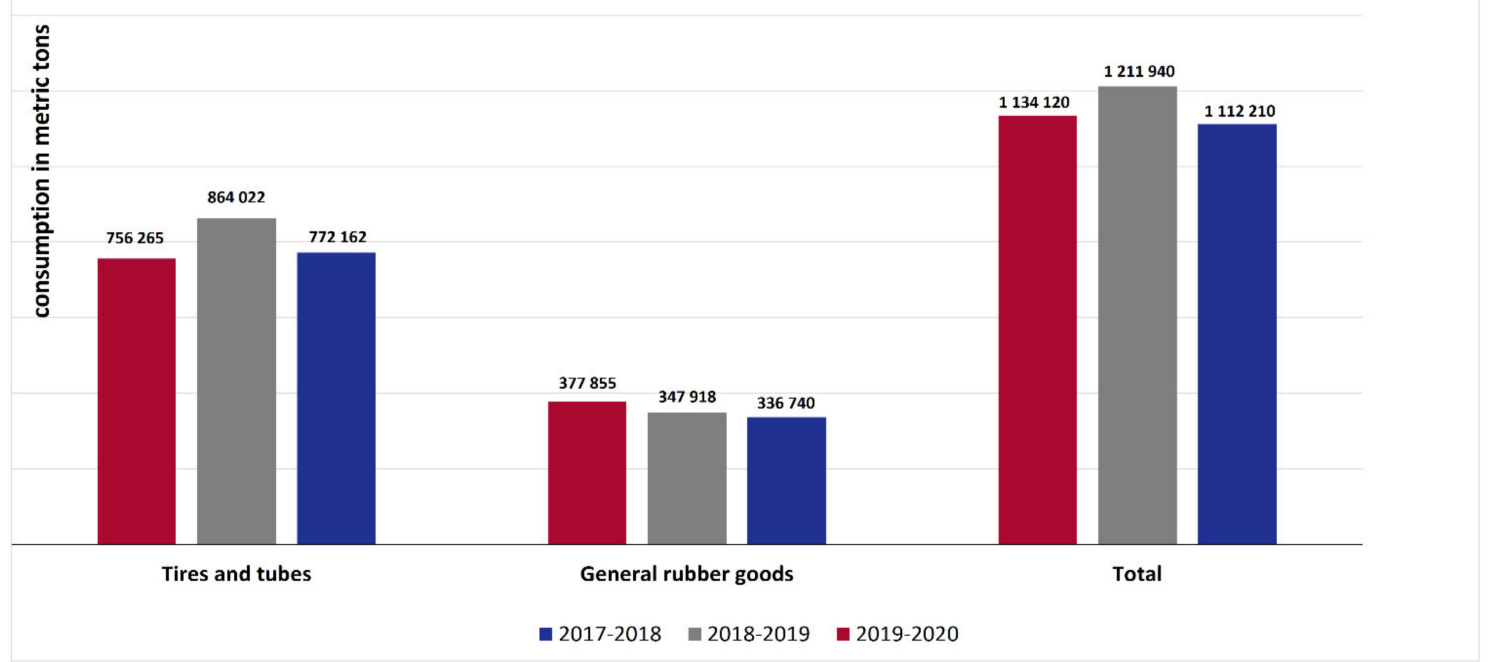

Figure 2. Consumption of natural rubber. Source: statista.com, 27 May 2021.

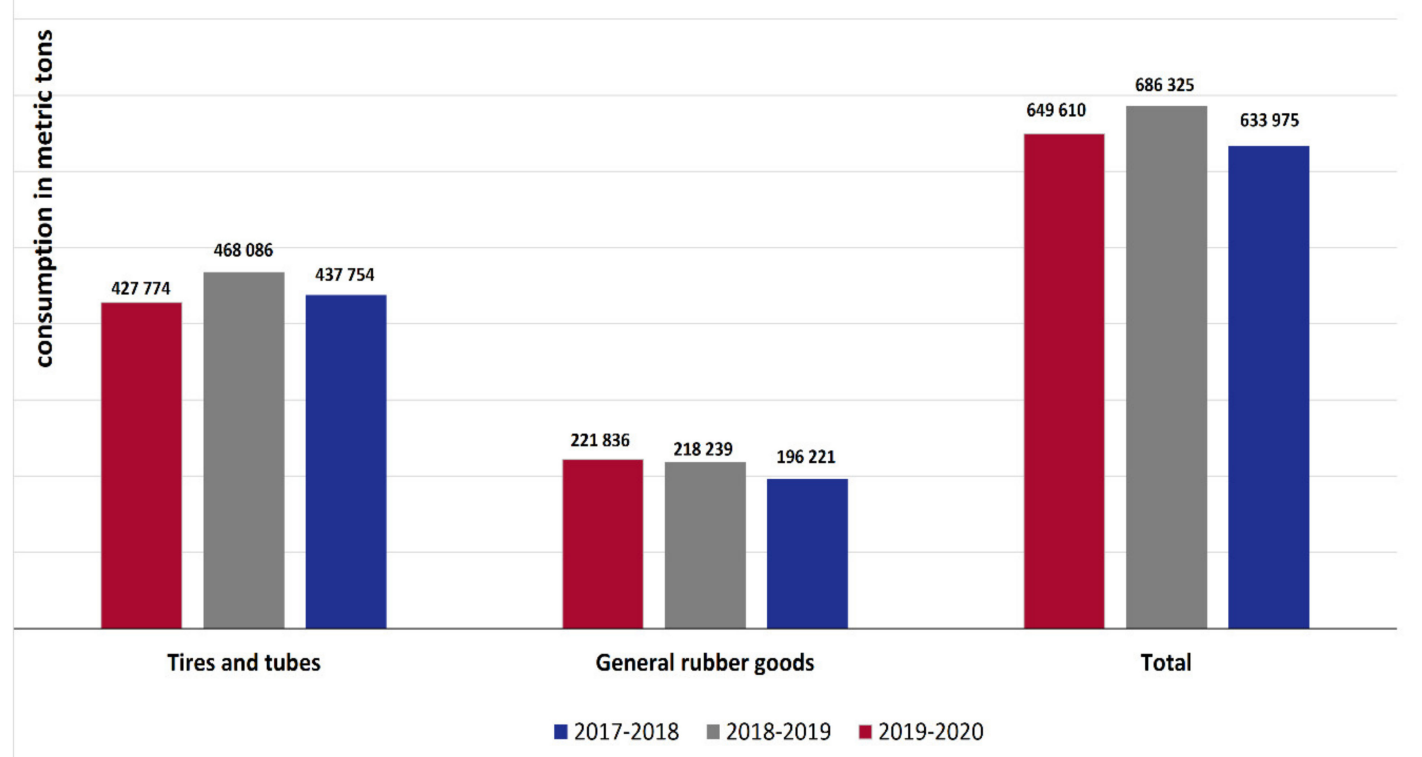

Figure 3. Consumption of synthetic rubber. Source: statista.com, 27 May 2021. 


\section{Current Usage of Waste Rubber}

\subsection{Waste-Tire Recycling Industry}

The global demand for tires will reach 3.2 billion units in 2022 [13]. A total of about 223 million replacement passenger tires were shipped to the USA in 2019 [14]. Scrap tires could take up space in landfills, or serve as breeding grounds for mosquitoes and rodents when stockpiled or illegally dumped [15]. The U.S. Tire Manufacturers Association published its 2019 Scrap Tire Management Report on 14 October. According to the report, tires remain one of the most recycled products in the U.S., but end-of-life markets are not keeping pace with the annual generation of scrap tires. The report reveals that nearly $76 \%$ of scrap tires have been recycled in products such as rubber-modified asphalt, automotive products, mulch for landscaping, and tire-derived fuel in 2019. This value is down from $96 \%$ in 2013, when scrap tire recycling peaked [16]. Tires are composed of various elements, including rubber/elastomers (45-47\%), carbon black (21.5-22\%), metals (12-25\%), textile $(0-10 \%)$, zinc oxide (1-2\%), sulfur (1\%), and additives (5-7.5\%) [17].

Landfilling requires huge capacities of space, as tires cannot be compressed to decrease space taken during disposal. To reduce the space occupied by waste tires in landfills, shredding waste tires prior to disposal is an option, but the high operating costs make this process impractical. Dispatching materials to landfills represent a lost chance in terms of a circular economy and deriving more value from waste. Some solutions can enable this substantial stream of rubber wastes to be converted into energy or new polymer materials [18]. Brown of Watson Brown HSM Ltd. (London, UK) [19] provided the next data for global estimates linked to rubber manufacturing life cycle [20]:

Total amount of rubber recycled at its end-of-life: typically, 3-15\%;

Total of waste rubber re-used in some way (e.g., retreading, new products, etc.): 5-23\%;

Total of waste rubber used for energy recovery: $25-60 \%$;

Total of waste rubber send out to landfill or stored: $20-30 \%$.

A report released in 2014 from the Recycling and Economic Development Initiative of South Africa mentioned that the tire waste in South Africa was 177,385 tons, and 32\% was diverted from landfill [21]. Figure 4 shows the general life cycle of a tire.

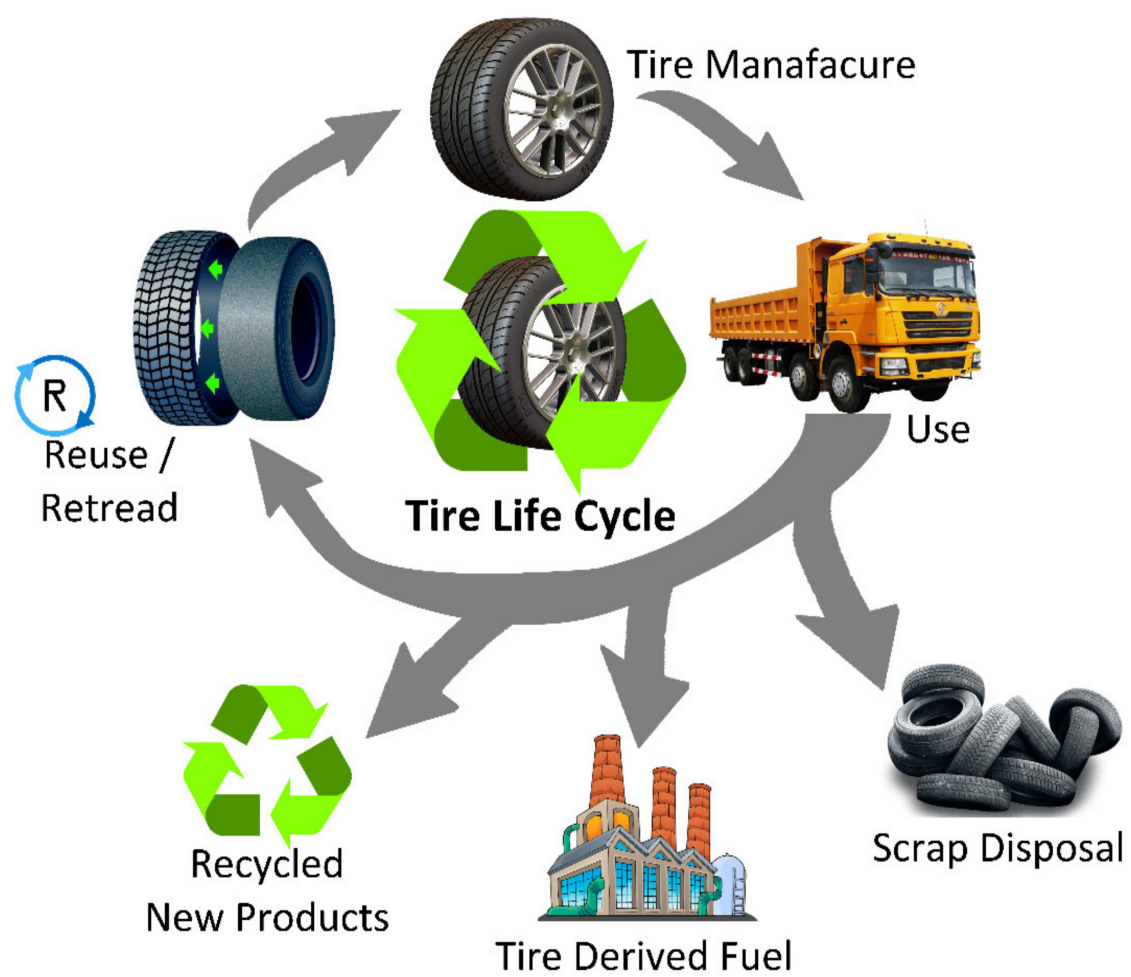

Figure 4. Life cycle of a tire. 


\subsection{Recycling Advantage}

The high consumption of rubber prompts us to identify a method of recycling to decrease this undesirable effect. The significant objective of recycling waste rubber is to protect the environment and to produce energy from waste rubber, such as the following: retrieving energy as fuel, cleaning leaking oil, dealing with the same product after some changes, reuse of products of thermal decomposition, regenerative rubber, and powdered rubber [22]. Moreover, waste polyethylene terephthalate bottles and waste rubber tires can be effective additives after certain treatments, which can increase the performance to asphalt and build firm pavements [23].

These benefits from recycling rubber differ regionally. For example, European countries' tire-recycling rates are almost $100 \%$, whereas the ratio is less than $20 \%$ in South Africa. Accordingly, the European Union is four times more efficient than South Africa [17]. Table 1 illustrates the current usage of rubber waste.

Table 1. Review of the current usage of rubber waste.

\begin{tabular}{cccc}
\hline Type of Product Waste & $\begin{array}{c}\text { Type of Rubber } \\
\text { (Natural/Synthetic) }\end{array}$ & $\begin{array}{c}\text { Method of } \\
\text { Reuse/Recycling }\end{array}$ & Reference \\
\hline Glove (nitrile) & Synthetic & Recycling & {$[24]$} \\
Tire & Combination & Both & {$[25,26]$} \\
Tubes & Combination & Both & {$[27,28]$} \\
Mattresses & Natural & Recycling & {$[29]$} \\
\hline
\end{tabular}

\subsection{Construction Field}

Some studies have shown that waste or recyclable rubber can be used as building aggregates or fillers that reduce the thermal conductivity for cementitious composites up to $50 \%$ [30]. A study shows that adding 30\% ripped rubber to concrete mixture yields the maximum results of compressive strength and modulus of elasticity test [31]. Moreover, the first research in South Korea about tire-derived fuel ash (TDFA) has shown that it may work as a binder material, and that adding TDFA to concrete can improve durability and mechanical performance owing to packing impact [32]. An article published in December 2020 shows that waste-rubber powder and thermoplastic polyurethane have waterproofing elements with an estimated percentage that can support subgrade and sub-base layers for protecting against damage from moisture, especially on high-speed railways [33].

\subsection{Sustainable Treatment}

Research has shown that using several devulcanization methods for waste tire rubber (WTR) can essentially and selectively split vulcanizate's crosslinks, whereas maintaining the polymeric chains can provide new sustainability pathway(s) for WTR. The generated compound has equivalent physical properties to that of the original source. This advanced release opens new possibilities for innovative economic opportunities worldwide [34]. Additional experiments have shown that waste ground tire rubber can exert an excellent reinforcing influence on SBR solution, owing to the existence of the core-shell structured carbon black after being degraded by a heterogeneous process to less than $150{ }^{\circ} \mathrm{C}$ by soybean oil [35]. Rubber wastes also originate from the footwear industry sector, wherein 10-20 parts per hundred ( $\mathrm{phr}$ ) ethylene-vinyl acetate elastomer waste is mixed with natural rubber, styrene-butadiene rubber or acrylonitrile-butadiene rubber, then the composites are vulcanized; no significant effects were observed on the crosslinking formation of mixture [36].

\section{Various Techniques for Using Waste Rubber as Fuel and Its Additive}

Pyrolysis oil from waste rubber is receiving great interest as alternative fuels. It is a complex mixture of hydrocarbons such as kerosene, gasoline and diesel. Meanwhile, fuel additives can generally be defined as any combination formulated to enhance the quality and effectiveness of fuel [37]. Examples of fuel additives are acetone, hydrogen, ether, 
nitromethane, and methanol. These chemicals could be synthesized from carbon dioxide, carbon monoxide, hydrogen, and methane, which could be generated from pyrolysis process.

\subsection{Tire-Derived Fuel (TDF)}

TDF is the most extensively used method to obtain energy from waste tires by mixing shredded rubber with coal or other fuels and then using it to power plant boilers or factories. Additionally, it is a crucial way to lower the levels of NO release by up to 75\% [38]. Recently, Choi et al. [39] described an application of TDF fly ash as filler in a heated mixture of asphalt by evaluating three substance fillers, namely, stone dust, hydrated lime, and cement.

More than 7500 tons of waste tires were recovered with TDF in Canada and used as an auxiliary fuel in a cement plant in 2005 [40]. Figure 5 illustrates the process flow diagram for TDF.

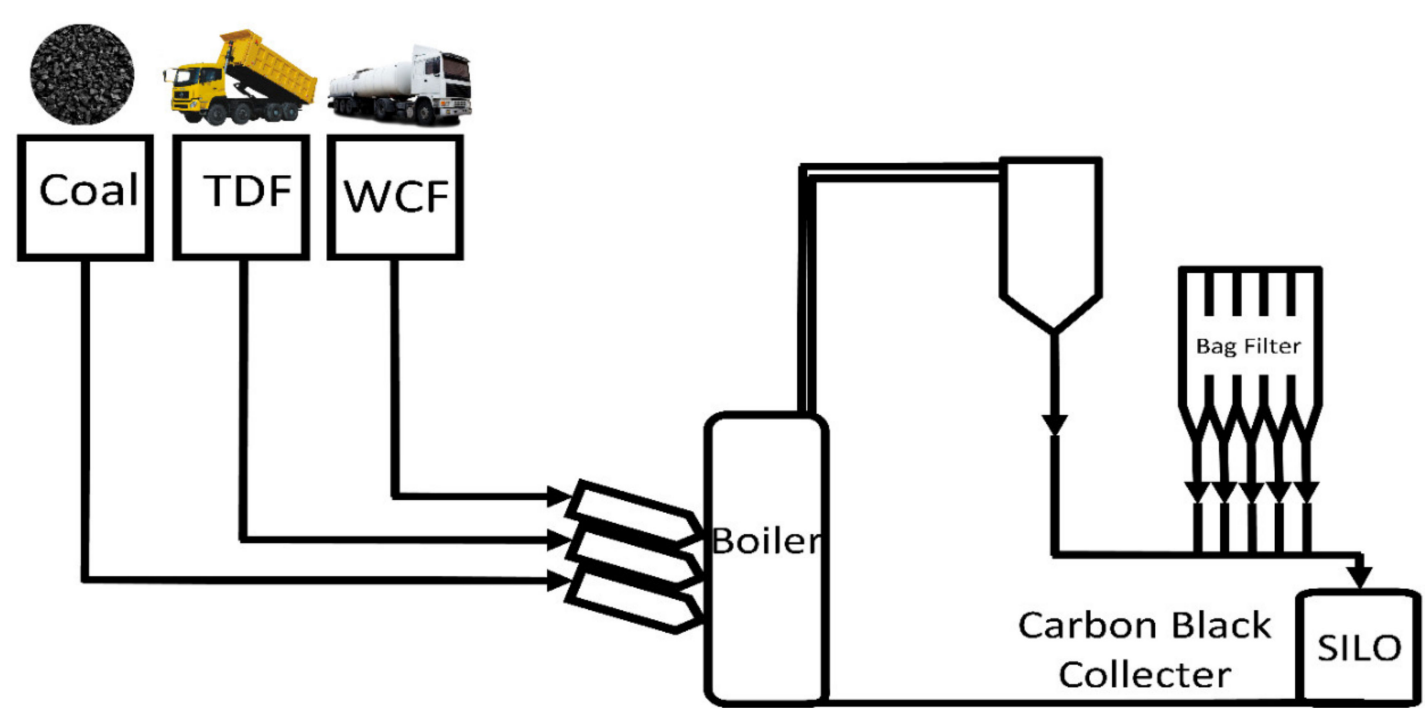

Figure 5. Tire-derived fuel PFD.

\subsection{Pyrolysis}

\subsubsection{Definition}

This section focuses on how rubber waste converted to secondary oil fuel has the same capability of the fuel itself through a process called pyrolysis. This technique for recycling adopts heat $\left(>400^{\circ} \mathrm{C}\right)$ for shredding tires in a reactor container under oxygen-free conditions [41]. Moreover, it is an alternative method dealing with vulcanized rubber to recover a useful product [42]. Substantial gases called pyrogas or syngas are released from pyrolysis (condensable and non-condensable compounds) and typically comprise paraffins and olefins [43]. Compounds such as methane and carbon dioxide are also released, but the major ones are a mixture of carbon monoxide and hydrogen $\left(\mathrm{H}_{2}\right.$ and $\left.\mathrm{CO}\right)$. The presence of large quantities of hydrocarbons $\left(\mathrm{C}_{2} \mathrm{H}_{6}\right),\left(\mathrm{C}_{2} \mathrm{H}_{4}\right),\left(\mathrm{C}_{3} \mathrm{H}_{8}\right),\left(\mathrm{C}_{3} \mathrm{H}_{6}\right),\left(\mathrm{C}_{4} \mathrm{H}_{10}\right),\left(\mathrm{C}_{4} \mathrm{H}_{8}\right)$, and $\left(\mathrm{C}_{4} \mathrm{H}_{6}\right)$, nitrogen compounds $\left(\mathrm{NH}_{3}\right)$, and sulphur compounds $\left(\mathrm{H}_{2} \mathrm{~S}, \mathrm{SO}_{2}, \mathrm{COS}\right.$, and $\left.\mathrm{CS}_{2}\right)$ at low concentrations has also been confirmed [44,45]. Figure 6 shows the process flow diagram for pyrolysis. 


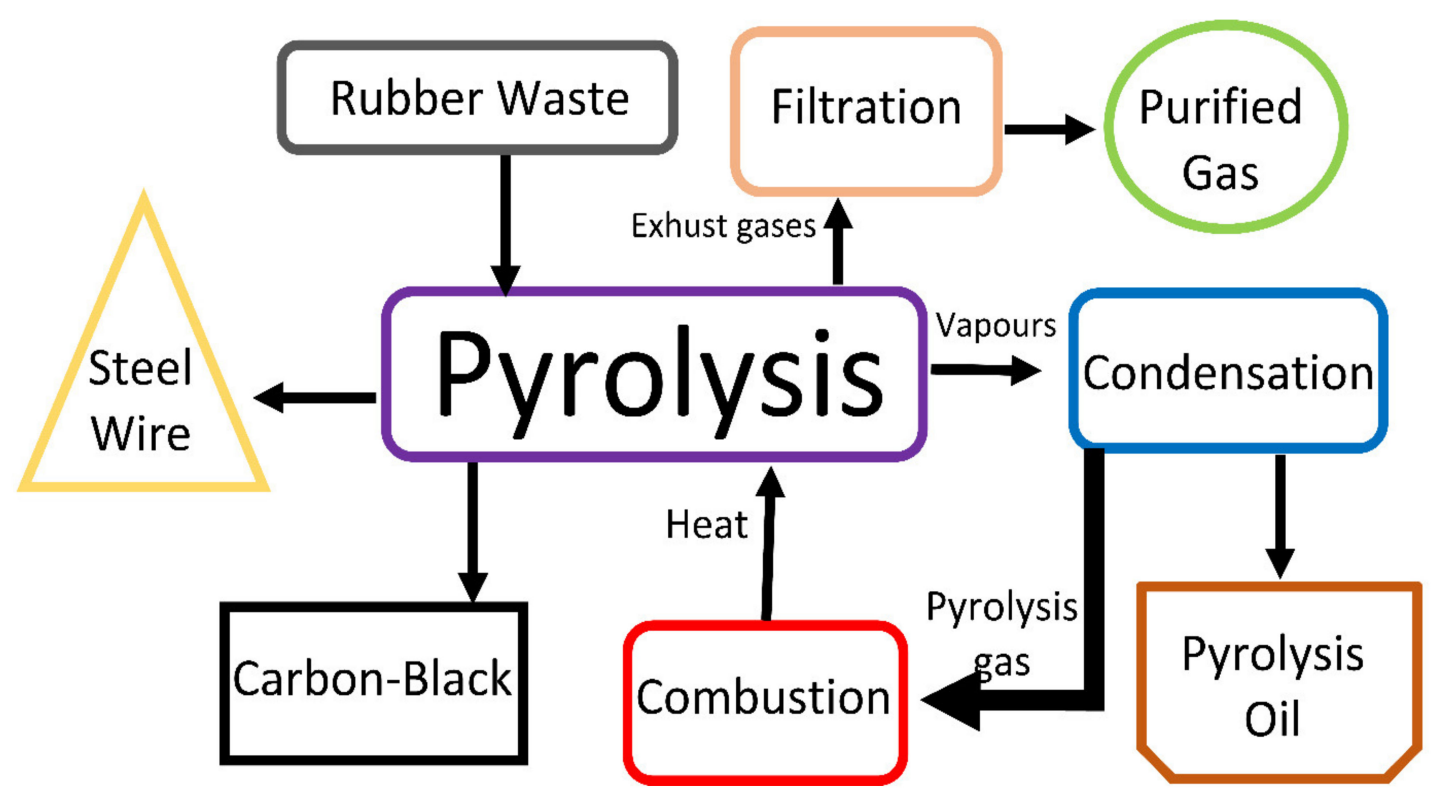

Figure 6. Pyrolysis PFD.

\subsubsection{Pyrolysis Reactors}

Scheirs mentions that reactor's shape and scale varies depending on usage and volume, from $3 \mathrm{~m}^{3}$ designed for laboratory use to $20 \mathrm{~m}^{3}$ used for manufacturing plants. Each kind has advantages and disadvantages in terms of technical, ecological and economic factors [46]. The most commonly used reactors are screw kiln, fixed bed (batch), rotary kiln, fluidized bed, and vacuum [47].

Additionally, Table 2 shows the ability of rubber waste to become a fuel or fuel enhancement.

Table 2. Various synthesis methods of fuel from rubber waste.

\begin{tabular}{cccc}
\hline Type of Product Waste & $\begin{array}{c}\text { Method of Production } \\
\text { of Fuel }\end{array}$ & $\begin{array}{c}\text { Fuel/Fuel Additives } \\
\text { Product }\end{array}$ & Reference \\
\hline Glove (nitrile) & co-pyrolysis & Fuel Additives & {$[48]$} \\
Tire & pyrolysis & Fuel & {$[49]$} \\
Tubes & pyrolysis & Fuel & {$[50]$} \\
Mattresses & pyrolysis & Fuel & {$[51]$} \\
\hline
\end{tabular}

\subsubsection{Types of Pyrolysis}

We can classify pyrolysis to two main types depending on the operational conditions, such as temperature, heating rate, and volatile residence time. Thus, general simple classifications of slow and fast are possible [52].

Slow Pyrolysis

Slow pyrolysis is also called carbonization. This kind of pyrolysis works at low temperatures and reflects a slow pyrolytic decomposition. Slow pyrolysis is characterized by low heating rates (a temperature range of $400-450{ }^{\circ} \mathrm{C}$ ) and fairly long solid and vapor residence times (minutes to hours) which lead to higher yields of coke, tar, and char (the main compound) [53]. Fixed-bed reactors (FBRs) are usually used for slow pyrolysis [49].

Fast Pyrolysis

Fast pyrolysis occurs at 500-600 ${ }^{\circ} \mathrm{C}$ [54]. Higher heating rates and short residence times (milliseconds to seconds) represent this type of pyrolysis. Fluidized beds, fixed beds, 
and vacuum are typically used to operate fast pyrolysis, which requires small particle sizes [55].

\section{Pyrolysis Parameters}

Waste tire pyrolysis is a heat-absorbing process supported by temperature in a reactor. Thus, temperature has the strongest influence on pyrolysis products and conversion rates [52].

Other influential factors include particle size, feedstock composition, and atmospheric pressure. The presence of a catalyst also has a remarkable effect on the process [56].

\subsection{Effect of Reactor Temperature and Pressure}

The main variable involved in tire pyrolysis is temperature $[57,58]$. Several researchers such as de Marco Rodriguez et al. and Uçar et al. $[59,60]$ stated that $500{ }^{\circ} \mathrm{C}$ is the optimum temperature at atmospheric pressure to achieve total tire conversion. Some studies have focused on the effect of pyrolysis-reactor temperature for the range of $200-600{ }^{\circ} \mathrm{C}$, wherein char yield markedly decreases with increased temperature. The liquid-fuel yield increases with increased temperature from $280{ }^{\circ} \mathrm{C}$ to $350{ }^{\circ} \mathrm{C}$. With further increased temperature, the liquid-fuel yield decreases. Conversely, gas yield increases with increased temperature from $280{ }^{\circ} \mathrm{C}$ to $400{ }^{\circ} \mathrm{C}$ [61]. Ilkiliç and Aydin [62] found that when the temperature reaches $400{ }^{\circ} \mathrm{C}$, liquid yield increases with increased temperature and reaches its peak value at $500{ }^{\circ} \mathrm{C}$ before slightly decreasing to become sluggish. By contrast, Alvarez [63] noted a decline in pyrolysis liquid yield when the process is carried out at similar temperatures in the range of $425-575^{\circ} \mathrm{C}$.

Meanwhile, gaseous yield grows at a roughly linearly rate with increased temperature [64]. Processes at very high temperatures in fluidized and spouted bed reactors normally face a phenomenon of increased solid fraction with increased pyrolysis temperature, as higher heating rates and the vigorous gas-solid contact can boost additional secondary reactions involving the solid pyrolytic carbon black particles $[65,66]$. Conesa [67] reported that at higher temperatures, solid fractions increase from $20.4 \mathrm{wt} \%$ at $600{ }^{\circ} \mathrm{C}$ to 32.5 wt. $\%$ at $900{ }^{\circ} \mathrm{C}$ by using bubbling FBR. However, in another publication, he used an FBR but did not find liquid-fraction production at $1000^{\circ} \mathrm{C}$, although a higher solid fraction comprising pyrolytic carbon black is observed [68].

\subsection{Effect of Reactor Pressure}

Another essential factor affecting pyrolysis is pressure. According to Buekens, increased pressure on feedstock pyrolysis that contain plastics leads more viscous liquid products with a higher coking tendency and more auxiliary and dehydrogenation reactions [53]. Ma et al. [69] examined the effects of pressure on limonene conversion during waste-tire pyrolysis. They found that yields of limonene substantially increase by about $20 \%$ during high-pressure pyrolysis with decreased residence time from $60 \mathrm{~s}$ to $15 \mathrm{~s}$. They also revealed that the mean yield of limonene at $1.0 \mathrm{MPa}$ is roughly 1.7 times larger than that of $0.1 \mathrm{MPa}$ at the same residence time. Additionally, vacuum pyrolysis lowers the incidence of secondary reactions in the vapor period compared with pyrolysis at atmospheric pressure. The residence time of volatiles in vacuum pyrolysis imposes a limitation to secondary reactions [70]. Bikane et al. [71] reported Morupule coal behavior during pyrolysis in a high-pressure wire-mesh reactor. The effect of pressure is clear at 600 and $800{ }^{\circ} \mathrm{C}$, i.e., total volatile yields decrease at higher pressures owing to the repolymerization of volatiles.

\subsection{Rubber-Waste Particle Size}

Previous studies have shown that the particle size of materials below $5 \mathrm{~mm}$ has no effect on reaction rates, as the temperature gradients within the particle are not considerable [72,73]. Furthermore, according to Beaumont and Schwob [74], heat transfer is difficult for larger particle sizes compared with small ones. As a result, the pyrolysis reaction is 
undertaken at a lower temperature. The size of tire particles and pyrolysis conversion are inversely related [75]. Dai et al. [76] used a CFBR at $500{ }^{\circ} \mathrm{C}$ and noticed a higher tire conversion rate and a drop in the pyrolytic CB yield from $45 \mathrm{wt} . \%$ to $30 \mathrm{wt} . \%$ when the tire particle size is reduced from $0.8 \mathrm{~mm}$ to $0.32 \mathrm{~mm}$.

Barbooti et al. [77] obtained greater liquid yield for lower particle sizes when using an FBR at $0.35 \mathrm{~m}^{3} / \mathrm{h}$ of $\mathrm{N} 2$ and heat at around $400-460{ }^{\circ} \mathrm{C}$. Oyedun et al. [78] found a significant consequence of the particle size on pyrolysis time. At $500{ }^{\circ} \mathrm{C}$ and $5{ }^{\circ} \mathrm{C} / \mathrm{min}$, the pyrolysis time is around $1.5 \mathrm{~h}$ for particles with a radius of $10 \mathrm{~mm}$ and $2.5 \mathrm{~h}$ for $50 \mathrm{~mm}$. Rofiqul Islam et al. [79] used an FBR at $475^{\circ} \mathrm{C}$ and found reduced liquid yield for particles $2 \mathrm{~cm}^{3}$ in size compared with that for $4 \mathrm{~cm}^{3}$ particles. Similarly, the pyrolytic $C B$ and the gas fraction are higher for $2 \mathrm{~cm}^{3}$ than for $4 \mathrm{~cm}^{3}$. We can assume that secondary reactions can also occur depending on the pyrolysis conditions.

Cylindrical tire particles with diameters between 7.5 and $22 \mathrm{~mm}$ have been devolatilized in a macro-TG reactor at temperatures between 490 and $840{ }^{\circ} \mathrm{C}$ in a spiritless environment by Larsen et al. [80]. The influence of particle size and surrounding temperature on the rate of devolatilization is noted to be significant. Thus, larger particle diameters and lower temperatures increase the pyrolysis period.

\subsection{Feedstock Composition}

The structures of tires vary depending on brand, type, and age [81,82]. Companies do not divulge the composition and the processing method of their tires, and they stay unrevealed [80]. Natural and synthetic rubber are found in different percentages in tires depending on the category (truck tire, passenger-car tire, and motorcycle tire). Today, tires are comprised of about $19 \%$ natural rubber and $24 \%$ synthetic rubber, which is a plastic polymer. The rest is made up of metal and other compound fillers [83]. The ratio of natural to synthetic rubber in TT is approximately 2:1 and nearly 4:3 in PCT [84].

Variations in the aromatic content of pyrolysis oil are reportedly associated with the original tire composition, especially the natural and synthetic rubber contents. For instance, Uçar et al. [60] observed that truck tires with a natural rubber content of $51 \mathrm{wt} . \%$ yields 15.4 vol. $\%$ aromatic content. Conversely, passenger-car tires with a lower natural rubber content of $35 \mathrm{wt} . \%$ produce a higher aromatic content of $41.5 \mathrm{vol} . \%$. Additionally, Seidelt et al. [85], noticed that for natural rubber primarily made of xylene and isoprene dimmer, the SBR generates ethylbenzene, stirene, and cumene.

Therefore, passenger car tires with higher synthetic rubber content are likely to deliver oil with greater value for chemical production, owing to their higher aromatic content. Truck tires with superior natural rubber content tend to produce oil with larger potential as a vehicle fuel due to its lower sulfur content [86].

\subsection{Pyrolysis Time}

Corresponding to [57], the pyrolysis time is also referred to as the residence time of the tire inside the reactor, or simply reaction time; from previous literature reviews we can determine that pyrolysis time is related directly to particle size, meaning larger particles size require longer residence times while, inversely, lower heating rates require longer pyrolysis times. Numerous studies have shown a time-temperature link, i.e., higher temperatures require shorter tire residence times, and lower temperatures require longer residence times $[87,88]$. Recently, a derivative relationship has been obtained between two parameters (characteristic heating time and pyrolysis time) for olive stone particles with constant values of bed temperature [89].

\subsection{Catalyst Role}

Catalysts can be used to enhance pyrolysis rate, oil yield, oil quality, and yields of composites such as aromatics for chemical production to boost pyrolysis rate and oil quality. Some researchers have attempted to use (ITQ-21 and ITQ-24) as additives to industrial HMOR zeolite for the catalytic pyrolysis of waste tires; Dũng et al. [90] indicated that the 
catalyst affects the yield of kerosene, gasoline, and asphaltenes in pyrolytic oils. However, Kar [91] heated expanded perlite (volcanic-origin rock comprised mostly of silica and alumina) up to $850^{\circ} \mathrm{C}$ to $1000{ }^{\circ} \mathrm{C}$, and produced a porous catalyst with which metals were then combined to serve as catalysts.

Pyrolysis catalysts are very expensive, so some experimental studies have attempted to prepare low-cost catalysts similar to fly ash for the pyrolysis of HDPE and LDPE plastics. Tests were conducted at variable mass fractions $(5 \%, 10 \%$, and $15 \%)$ of catalyst. The maximum yield was $5 \%$, and it decreases with further addition of catalyst. Conversely, any increase in mass portion of catalyst leads to reduced reaction temperature and retention periods [92]. Chen et al. [93] reported that applying high-alkalinity red mud as a catalyst for coal pyrolysis in a fixed bed and the $\mathrm{CO}_{2}$ gasification of its resultant char improves the quality of tar and increases its weight percentage by $20.0 \%$ compared with coal pyrolysis alone.

Table 3 summarizes the effects of various parameters on fuel-additive production.

Table 3. Effects of pyrolysis processing parameters on fuel-additive production from rubber waste.

\begin{tabular}{ccc}
\hline Processing Parameters Used & $\begin{array}{c}\text { Made of } \\
\text { (Natural/Synthetic Rubber Waste) }\end{array}$ & Reference \\
\hline Temperature & Combination & {$[94]$} \\
Higher heating & Synthetic & {$[95]$} \\
Particle Size & Combination & {$[96]$} \\
Feedstock Composition & & {$[53]$} \\
Residence Time & Synthetic & {$[97]$} \\
Atmospheric Pressure & & {$[98]$} \\
Catalyst & & {$[99]$} \\
\hline
\end{tabular}

\section{Process Improvements for Pyrolysis to Be More Environmentally Acceptable}

The use of liquid products from scrap rubber by combusting them in an internal combustion engine is one technique that may be less damaging to the natural environment [100]. It was also suggested that chemical recycling is undoubtedly energy consumption, especially during the pyrolysis process [101]. Besides a wide range of benefits to the community and economic sector, more research and development on the pyrolysis process needs to be explored, especially related to the environmental aspect. Qijing Wu et al. concluded that the pyrolysis-based high-value utilization of waste tires has more benefits compared to the conventional pyrolysis. Results showed reducing energy usage has a positive influence on reduction in major environmental effects; this resource saving is followed by environmental protection. Moreover, over $90 \%$ of the ecological impacts of ozone layer depletion and pollutants are decreased, and over $85 \%$ of the environmental loads of abiotic mineral and fossil fuel depletion are reduced [102].

Microwave pyrolysis is another possible technology to be explored. It has gained wide approval in the eyes of thermal chemistry scientists and presents more profits [103]. Electromagnetic rays of microwaves can be conveyed during the material directly. The processing has been claimed to provide many benefits, including environmental friendliness and process time reductions [104]. Chia Yang and Ani improved a controlled microwave heating technique by using activated carbon as a catalyst, due to its characteristic as a good microwave absorber, this study could contribute to carbon dioxide emission reduction and a move toward sustainable energy usage. Additionally, as the heating temperature rises quicker, and the heating duration is reduced, this will contribute in energy savings [105]. Recently, an experiment by Jin Hu indicated that applying ultraviolet (UV) will accelerate the aging of granules of plastics prior pyrolysis process. This will contribute to total energy saving [106]. According to Mohajerani et al. the life cycle assessment (LCA) analysis for recycling discarded rubber tires in building materials yielded certain advantages in terms of human health and environmental effect [107]. According to a review paper by 
Sienkiewicz et al., rubber waste can be an environmentally friendly component after being converted as filler in polymer-rubber composites [108].

\section{Environmental Assessment Outcomes}

Table 4 shows the power consumption and gas emissions for different possible methods for rubber recycling. It was observed that pyrolysis could contribute higher amounts hazardous gases to environment. However, possible technology such as microwave pyrolysis would significantly reduce the power consumption. Additionally, the pyrolysis process would become a more environmentally friendly process.

Table 4. The amount of energy and gas emissions generated by various techniques of rubber recycling.

\begin{tabular}{|c|c|c|c|c|}
\hline Recycling Type & $\begin{array}{l}\text { Power } \\
\text { KW }\end{array}$ & $\begin{array}{c}\mathrm{CO}_{2} \\
\text { Emission }\end{array}$ & $\begin{array}{l}\text { Hazardous Gas Release } \\
\qquad\left(\mathrm{H}_{2} \mathrm{~S}, \mathrm{CO} \text {, etc. }\right)\end{array}$ & Reference \\
\hline Pyrolysis & 15 & $2.9 \%$ & $3.5 \%$ & {$[109,110]$} \\
\hline Microwave Pyrolysis & $3(2.45 \mathrm{GHz})$ & $<1 \%$ & $<1 \%$ & [111] \\
\hline $\begin{array}{c}\text { Thermo-mechanical recycling } \\
\text { (devulcanization) }\end{array}$ & 9 & - & - & [112] \\
\hline
\end{tabular}

\section{Conclusions and Future Aspects of Rubber Waste as a Fuel Additive}

Waste tires are perfect candidates for pyrolysis to recover energy owing to their origin (petroleum source). Moreover, temperature is the dominant factor influencing the physical and chemical properties of pyrolysis products, gas, liquid, and solid. Other prominent factors include reactor pressure, particle size, heating rate, feedstock composition, pyrolysis time/tire residence time, and catalyst role.

Additionally, $500^{\circ} \mathrm{C}$ appears to be the premium temperature at atmospheric pressure after achieving total tire conversion. Processes at very high temperatures (over $1000^{\circ} \mathrm{C}$ ) usually lead to increased solid fraction, therefore made a boost to additional secondary reactions involving the solid pyrolytic Carbon Black particle with no liquid fraction production.

Future research related to waste rubber is needed to establish a new development model for increasing oil yield as a function of major parameters, including temperature, heating rate, type of reactor, and rubber particle size. This effort would certainly contribute to reduce the ongoing struggle against the climate crisis.

Author Contributions: Resources and writing (original draft preparation and editing), A.A.; Supervision and writing (review and editing), N.Y.Y. All authors have read and agreed to the published version of the manuscript.

Funding: This research was funded by Ministry of Higher Education Malaysia grant number. FRGS/1/2018/TK05/UKM/02/4. The APC was not funded by external funding.

Institutional Review Board Statement: Not applicable.

Informed Consent Statement: Not applicable.

Data Availability Statement: Not applicable.

Acknowledgments: The authors would like to acknowledge Universiti Kebangsaan Malaysia (UKM, Bangi), Malaysia and Ministry of Higher Education Malaysia, for the financial support grant No. FRGS/1/2018/TK05/UKM/02/4.

Conflicts of Interest: The authors declare no conflict of interest.

\section{References}

1. Liquete, C.; Piroddi, C.; Drakou, E.; Gurney, L.; Katsanevakis, S.; Charef, A.; Egoh, B. Current Status and Future Prospects for the Assessment of Marine and Coastal Ecosystem Services: A Systematic Review. PLoS ONE 2013, 8, e67737. [CrossRef]

2. Costanza, R.; D’Arge, R.; De Groot, R.; Farber, S.; Grasso, M.; Hannon, B.; Limburg, K.; Naeem, S.; O’Neill, R.V.; Paruelo, J.; et al. The value of the world's ecosystem services and natural capital. Nature 1997, 387, 253-260. [CrossRef]

3. Capolupo, M.; Sørensen, L.; Jayasena, K.D.R.; Booth, A.M.; Fabbri, E. Chemical composition and ecotoxicity of plastic and car tire rubber leachates to aquatic organisms. Water Res. 2020, 169, 115270. [CrossRef] [PubMed] 
4. $\quad$ Beaumont, N.J.; Aanesen, M.; Austen, M.C.; Börger, T.; Clark, J.R.; Cole, M.; Hooper, T.; Lindeque, P.K.; Pascoe, C.; Wyles, K.J. Global ecological, social and economic impacts of marine plastic. Mar. Pollut. Bull. 2019, 142, 189-195. [CrossRef] [PubMed]

5. Bergmann, M.; Gutow, L.; Klages, M. Marine Anthropogenic Litter; Springer: Gothenburg, Sweden, 2015 ; pp. 1-447.

6. Barboza, L.G.; Cózar, A.; Gimenez, B.C.; Barros, T.L.; Kershaw, P.J.; Guilhermino, L. Microplastics Pollution in the Marine Environment, World Seas: An Environmental Evaluation Volume III: Ecological Issues and Environmental Impacts; Elsevier: London, UK, 2018; pp. 329-351.

7. GESAMP. Joint Group of Experts on the Scientific Aspects of Marine Environmental Protection. Sources, fate and effects of microplastics in the marine environment: A global assessment. Rep. Stud. GESAMP 2015, 90, 96.

8. Geyer, R.; Jambeck, J.R.; Law, K.L. Production, use, and fate of all plastics ever made. Sci. Adv. 2017, 3, e1700782. [CrossRef] [PubMed]

9. Jambeck, J.R.; Geyer, R.; Wilcox, C.; Siegler, T.R.; Perryman, M.; Andrady, A.; Narayan, R.; Law, K.L. Plastic waste inputs from land into the ocean. Science 2015, 347, 768-771. [CrossRef] [PubMed]

10. Andrady, A.L. Persistence of Plastic Litter in the Oceans. In Marine Anthropogenic Litter; Springer: Singapore, $2015 ;$ pp. 57-72.

11. Ophardt, C.E. Virtual Chembook, Boiling Points of Hydrocarbons. Available online: http://chemistry.elmhurst.edu/vchembook/ 403rubber.html (accessed on 27 May 2021).

12. Greve, H.-H.; Threadingham, D.R. Survey, Ullmann's Encyclopedia of Industrial Chemistry; Wiley: New York, NY, USA, 2000.

13. Global Tires. The Freedonia Group. Available online: https://www.freedoniagroup.com/industry-study/global-tires-3687.htm (accessed on 27 May 2021).

14. Statista U.S. Original Equipment Passenger Tire Shipments 2017-2019. 2020. Available online: https://www.statista.com/ statistics /276159/passenger-tire-shipments-in-the-united-states/ (accessed on 27 May 2021).

15. Basic Information Scrap Tires US EPA. Available online: https://archive.epa.gov/epawaste/conserve/materials/tires/web/ html/basic.html (accessed on 27 May 2021).

16. Redling PBA. Scrap Tire Recycling Markets Not Keeping Pace with Generation, Report Shows. Recycling Today. Available online: https:/ / www.recyclingtoday.com/article/united-states-scrap-tire-recycling-markets-2019/ (accessed on 27 May 2021).

17. Sebola, M.; Mativenga, P.; Pretorius, J. A Benchmark Study of Waste Tyre Recycling in South Africa to European Union Practice. Proc. CIRP 2018, 69, 950-955. [CrossRef]

18. Sienkiewicz, M.; Kucinska-Lipka, J.; Janik, H.; Balas, A. Progress in used tyres management in the European Union: A review. Waste Manag. 2012, 32, 1742-1751. [CrossRef]

19. Brown, D. Proceedings of the Recycling of Rubber Meeting; Institute of Materials: London, UK, 2008.

20. Forrest, M.J. Recycling and Re-Use of Waste Rubber; De Gruyter: Boston, MA, USA; Berlin, Germany, 2019.

21. REDISA (Recycling and Economic Development Initiative of South Africa). Annual Report. 2015. Available online: http: / / www.redisa.org.za/Satellite/000161\%20-\%20REDISA\%20Annual\%20Report\%20v5.pdf (accessed on 27 May 2021).

22. Fang, Y.; Zhan, M.; Wang, Y. The status of recycling of waste rubber. Mater. Des. 2000, 22, 123-127. [CrossRef]

23. Xu, X.; Leng, Z.; Lan, J.; Wang, W.; Yu, J.; Bai, Y.; Sreeram, A.; Hu, J. Sustainable Practice in Pavement Engineering through Value-Added Collective Recycling of Waste Plastic and Waste Tyre Rubber. Engineering 2021, 7, 857-867. [CrossRef]

24. Kumar Mishra, R.; Mohanty, K. Co-pyrolysis of waste biomass and waste plastics (polystyrene and waste nitrile gloves) into renewable fuel and value-added chemicals. Carbon Resour. Convers. 2020, 3, 145-155. [CrossRef]

25. Hamdi, A.; Abdelaziz, G.; Farhan, K.Z. Scope of reusing waste shredded tires in concrete and cementitious composite materials: A review. J. Build. Eng. 2021, 35, 102014. [CrossRef]

26. Verma, P.; Zare, A.; Jafari, M.; Bodisco, T.; Rainey, T.; Ristovski, Z.; Brown, R.J. Diesel engine performance and emissions with fuels derived from waste tyres. Sci. Rep. 2018, 8, 2457. [CrossRef]

27. Karaagac, B.; Şen, M.; Deniz, V.; Güven, O. Recycling of gamma irradiated inner tubes in butyl based rubber compounds. Nucl. Instrum. Methods Phys. Res. Sect. B Beam Interact. Mater. At. 2007, 265, 290-293. [CrossRef]

28. Recyclebank. Because You Asked: Are Bike Inner Tubes Recyclable? Available online: https://livegreen.recyclebank.com/ column/because-you-asked/are-bike-inner-tubes-recyclable (accessed on 27 May 2021).

29. Johnson, A. Keep Mattresses out of the Landfill—Green Business Bureau. Available online: https://greenbusinessbureau.com/ blog/keep-mattresses-out-of-the-landfill (accessed on 27 May 2021).

30. Adesina, A. Overview of the influence of waste materials on the thermal conductivity of cementitious composites. Clean. Eng. Technol. 2021, 2, 100046. [CrossRef]

31. Taak, N.; Sharma, L.; Lallotra, B. Influence of Compression Casting Technique and Chipped Rubber Usage on the Strength Parameters of Concrete; Elsevier: Chandigarh, India, 2021; Volume 45, pp. 3462-3468.

32. Hyeok-Jung, K.; Sang-Min, P.; Subbiah, K.; Seung-Jun, K. Durability performance evaluation of concrete containing TDFA (Tire Derived Fuel Ash). Constr. Build. Mater. 2017, 133, 376-386. [CrossRef]

33. Xiao, X.; Wang, J.; Cai, D.; Lou, L.; Xiao, F. A novel application of thermoplastic polyurethane/waste rubber powder blend for waterproof seal layer in high-speed railway. Transp. Geotech. 2021, 27, 100503. [CrossRef]

34. Saputra, R.; Walvekar, R.; Khalid, M.; Mubarak, N.M.; Sillanpää, M. Current progress in waste tire rubber devulcanization. Chemosphere 2021, 265, 129033. [CrossRef]

35. Song, P.; Wan, C.; Xie, Y.; Formela, K.; Wang, S. Vegetable derived-oil facilitating carbon black migration from waste tire rubbers and its reinforcement effect. Waste Manag. 2018, 78, 238-248. [CrossRef] 
36. Lopes, D.; Ferreira, M.J.; Russo, R.; Dias, J.M. Natural and synthetic rubber/waste-Ethylene-Vinyl Acetate composites for sustainable application in the footwear industry. J. Clean. Prod. 2015, 92, 230-236. [CrossRef]

37. Corrosionpedia. Fuel Additives. Available online: https://www.corrosionpedia.com/definition/1625/fuel-additives-corrosion (accessed on 27 May 2021).

38. Singh, S.; Nimmo, W.; Gibbs, B.; Williams, P. Waste tyre rubber as a secondary fuel for power plants. Fuel 2009, 88, 2473-2480. [CrossRef]

39. Choi, M.J.; Kim, Y.J.; Kim, H.J.; Lee, J.J. Performance evaluation of the use of tire-derived fuel fly ash as mineral filler in hot mix asphalt concrete. J. Traffic Transp. Eng. 2020, 7, 249-258. [CrossRef]

40. Pegg, M.J.; Amyotte, P.R.; Fels, M.; Cumming, C.R.; Poushay, J.C. An Assessment of the Use of Tires as an Alternative Fuel; Final Report; Minist Environ Labour Nov Scotia Environ Labour: Halifax, NS, Canada, 2007.

41. Clark, C.; Meardon, K.; Russell, D. Burning Tires for Fuel and Tire Pyrolysis: Air Implications; Environmental Protection Agency (EPA): North Carolina, CA, USA, 1991.

42. Ramirez-Canon, A.; Muñoz-Camelo, Y.F.; Singh, P. Decomposition of Used Tyre Rubber by Pyrolysis: Enhancement of the Physical Properties of the Liquid Fraction Using a Hydrogen Stream. Environment 2018, 5, 72. [CrossRef]

43. Bennett, G. Scrap Tire Technology and Markets; Elsevier: Washington, DC, USA, 1993.

44. Kan, T.; Strezov, V.; Evans, T. Fuel production from pyrolysis of natural and synthetic rubbers. Fuel 2017, 191, 403-410. [CrossRef]

45. Zhang, X.; Wang, T.; Ma, L.; Chang, J. Vacuum pyrolysis of waste tires with basic additives. Waste Manag. 2008, 28, 2301-2310. [CrossRef]

46. Scheirs, J. Overview of Commercial Pyrolysis Processes for Waste Plastics. Feedstock Recycl. Pyrolysis Waste Plast. Convert. Waste Plast. Diesel Other Fuels 2006, 24, 381-433.

47. Williams, P. Pyrolysis of waste tyres: A review. Waste Manag. 2013, 33, 1714-1728. [CrossRef]

48. Mishra, R.K.; Iyer, J.S.; Mohanty, K. Conversion of waste biomass and waste nitrile gloves into renewable fuel. Waste Manag. 2019, 89, 397-407. [CrossRef]

49. Okoro, E.E.; Sanni, S.; Emetere, M.; Orodu, D. Process Scheme for the Production of Liquid Fuel from used tires via Fast Pyrolysis. Proc. Manuf. 2019, 35, 847-853. [CrossRef]

50. Mabood, F.; Jan, M.R.; Jabeen, F. Catalytic pyrolysis of waste inner rubber tube into fuel oil using alumina and calcium carbonate base catalysts. J. Chem. Soc. Pak. 2011, 33, 38-42.

51. Veses, A.; Sanahuja-Parejo, O.; Martínez, I.; Callén, M.S.; López, J.M.; García, T.; Murillo, R. A pyrolysis process coupled to a catalytic cracking stage: A potential waste-to-energy solution for mattress foam waste. Waste Manag. 2021, 120, 415-423. [CrossRef]

52. Martínez, J.D.; Puy, N.; Murillo, R.; García, T.; Navarro, M.V.; Mastral, A.M. Waste tyre pyrolysis-A review. Renew. Sustain. Energy Rev. 2013, 23, 179-213. [CrossRef]

53. Buekens, A. Introduction to Feedstock Recycling of Plastics. In Feedstock Recycling and Pyrolysis of Waste Plastics: Converting Waste Plastics into Diesel and Other Fuels; Wiley: Brussels, Belgium, 2006; pp. 1-41.

54. Venderbosch, R.; Prins, W. Fast pyrolysis technology development. Biofuels Bioprod. Biorefin. 2010, 4, 178-208. [CrossRef]

55. Cunliffe, A.M.; Williams, P.T. Composition of oils derived from the batch pyrolysis of tyres. J. Anal. Appl. Pyrolysis 1998, 44, 131-152. [CrossRef]

56. Murillo, R.; Aylón, E.; Navarro, M.V.; Callén, M.; Aranda, A.; Mastral, A. The application of thermal processes to valorise waste tyre. Fuel Process. Technol. 2006, 87, 143-147. [CrossRef]

57. Aylón, E.; Fernández-Colino, A.; Murillo, R.; Navarro, M.V.; García, T.; Mastral, A.M. Valorisation of waste tyre by pyrolysis in a moving bed reactor. Waste Manag. 2010, 30, 1220-1224. [CrossRef]

58. Mastral, A.M.; Murillo, R.; Callén, M.S.; García, T.; Snape, C. Influence of Process Variables on Oils from Tire Pyrolysis and Hydropyrolysis in a Swept Fixed Bed Reactor. Energy Fuels 2000, 14, 739-744. [CrossRef]

59. De Marco Rodriguez, I.; Laresgoiti, M.F.; Cabrero, M.A.; Torres, A.; Chomon, M.J.; Caballero, B. Pyrolysis of scrap tyres. Fuel Process Technol. 2001, 72, 9-22. [CrossRef]

60. Ucar, S.; Karagoz, S.; Ozkan, A.R.; Yanik, J. Evaluation of two different scrap tires as hydrocarbon source by pyrolysis. Fuel 2005, 84, 1884-1892. [CrossRef]

61. Shah, J.; Jan, M.R.; Mabood, F. Catalytic conversion of waste tyres into valuable hydrocarbons. J. Polym. Environ. 2007, 15, 207-211. [CrossRef]

62. Ilkılıç, C.; Aydın, H. Fuel production from waste vehicle tires by catalytic pyrolysis and its application in a diesel engine. Fuel Process. Technol. 2011, 92, 1129-1135. [CrossRef]

63. Alvarez, J.; Lopez, G.; Amutio, M.; Mkhize, N.; Danon, B.; van der Gryp, P.; Gorgens, J.; Bilbao, J.; Olazar, M. Evaluation of the properties of tyre pyrolysis oils obtained in a conical spouted bed reactor. Energy 2017, 128, 463-474. [CrossRef]

64. Aydın, H.; Ilkılıç, C. Optimization of fuel production from waste vehicle tires by pyrolysis and resembling to diesel fuel by various desulfurization methods. Fuel 2012, 102, 605-612. [CrossRef]

65. Kaminsky, W.; Mennerich, C.; Zhang, Z. Feedstock recycling of synthetic and natural rubber by pyrolysis in a fluidized bed. J. Anal. Appl. Pyrolysis 2009, 85, 334-337. [CrossRef]

66. Lopez, G.; Olazar, M.; Aguado, R.; Bilbao, J. Continuous pyrolysis of waste tyres in a conical spouted bed reactor. Fuel 2010, 89, 1946-1952. [CrossRef] 
67. Conesa, J.A.; Font, A.R.; Marcilla, A. Gas from the Pyrolysis of Scrap Tires in a Fluidized Bed Reactor. Energy Fuels 1996, 10, 134-140. [CrossRef]

68. Conesa, J.A.; Martín-Gullón, I.; Font, R.; Jauhiainen, J. Complete Study of the Pyrolysis and Gasification of Scrap Tires in a Pilot Plant Reactor. Environ. Sci. Technol. 2004, 38, 3189-3194. [CrossRef]

69. Ma, S.; Leong, H.; He, L.; Xiong, Z.; Han, H.; Jiang, L.; Wang, Y.; Hu, S.; Su, S.; Xiang, J. Effects of pressure and residence time on limonene production in waste tires pyrolysis process. J. Anal. Appl. Pyrolysis 2020, 151, 104899. [CrossRef]

70. Li, S.-Q.; Yao, Q.; Chi, Y.; Yan, A.J.-H.; Cen, K.-F. Pilot-Scale Pyrolysis of Scrap Tires in a Continuous Rotary Kiln Reactor. Ind. Eng. Chem. Res. 2004, 43, 5133-5145. [CrossRef]

71. Bikane, K.; Yu, J.; Long, X.; Paterson, N.; Millan, M. Linking char reactivity to structural and morphological evolution during high pressure pyrolysis of Morupule coal. Chem. Eng. Sci. X 2020, 8, 100072. [CrossRef]

72. González, J.F.; Encinar, J.M.; Canito, J.L.; Rodríguez, J.J. Pyrolysis of automobile tyre waste. Influence of operating variables and kinetics study. J. Anal. Appl. Pyrolysis 2001, 58-59, 667-683. [CrossRef]

73. Encinar, J.; González, J.F.G. Fixed-bed pyrolysis of Cynara cardunculus L. Product yields and compositions. Fuel Process. Technol. 2000, 68, 209-222. [CrossRef]

74. Beaumont, O.; Schwob, Y. Influence of physical and chemical parameters on wood pyrolysis. Ind. Eng. Chem. Process. Des. Dev. 1984, 23, 637-641. [CrossRef]

75. Bouvier, J.; Charbel, F.; Gelus, M. Gas-solid pyrolysis of tire wastes-Kinetics and material balances of batch pyrolysis of used tires. Resour. Conserv. 1987, 15, 205-214. [CrossRef]

76. Dai, X.; Yin, X.; Wu, C.; Zhang, W.; Chen, Y. Pyrolysis of waste tires in a circulating fluidized-bed reactor. Energy 2001, 26, 385-399. [CrossRef]

77. Barbooti, M.; Mohamed, T.J.; Hussain, A.A.; Abas, F.O. Optimization of pyrolysis conditions of scrap tires under inert gas atmosphere. J. Anal. Appl. Pyrolysis 2004, 72, 165-170. [CrossRef]

78. Oyedun, A.O.; Lam, K.L.; Fittkau, M.; Hui, C.-W. Optimisation of particle size in waste tyre pyrolysis. Fuel 2012, 95, 417-424. [CrossRef]

79. Rofiqul Islam, M.; Haniu, H.; Rafiqul Alam Beg, M. Liquid fuels and chemicals from pyrolysis of motorcycle tire waste: Product yields, compositions and related properties. Fuel 2008, 87, 3112-3122. [CrossRef]

80. Larsen, M.B.; Schultz, L.; Glarborg, P.; Skaarup-Jensen, L.; Dam-Johansen, K.; Frandsen, F.; Henriksen, U.B. Devolatilization characteristics of large particles of tyre rubber under combustion conditions. Fuel 2006, 85, 1335-1345. [CrossRef]

81. Williams, P.T.; Besler, S. Pyrolysis-thermogravimetric analysis of tyres and tyre components. Fuel 1995, 74, 1277-1283. [CrossRef]

82. Kyari, M.; Cunliffe, A.; Williams, P.T. Characterization of Oils, Gases, and Char in Relation to the Pyrolysis of Different Brands of Scrap Automotive Tires. Energy Fuels 2005, 19, 1165-1173. [CrossRef]

83. Root, T. Nationalgeographic, Tires: The Plastic Polluter You Never Thought about. Available online: https://www. nationalgeographic.com/environment/article/tires-unseen-plastic-polluter (accessed on 27 May 2021).

84. Shulman, V.L. Tyre Recycling. In Waste; European Tyre Recycling Association (ETRA): Brussels, Belgium, 2011; pp. 297-320. [CrossRef]

85. Seidelt, S.; Müller-Hagedorn, M.; Bockhorn, H. Description of tire pyrolysis by thermal degradation behaviour of main components. J. Anal. Appl. Pyrolysis 2006, 75, 11-18. [CrossRef]

86. Alsaleh, A.; Sattler, M.L. Waste Tire Pyrolysis: Influential Parameters and Product Properties. Curr. Sustain. Energy Rep. 2014, 1, 129-135. [CrossRef]

87. Olazar, M.; Lopez, G.; Arabiourrutia, M.; Elordi, G.; Aguado, R.; Bilbao, J. Kinetic modelling of tyre pyrolysis in a conical spouted bed reactor. J. Anal. Appl. Pyrolysis 2008, 81, 127-132. [CrossRef]

88. Cheung, K.-Y.; Lee, K.-L.; Lam, K.-L.; Chan, T.-Y.; Lee, C.-W.; Hui, C.-W. Operation strategy for multi-stage pyrolysis. J. Anal. Appl. Pyrolysis 2011, 91, 165-182. [CrossRef]

89. Soria-Verdugo, A.; Rubio-Rubio, M.; Goos, E.; Riedel, U. On the characteristic heating and pyrolysis time of thermally small biomass particles in a bubbling fluidized bed reactor. Renew. Energy 2020, 160, 312-322. [CrossRef]

90. Dũng, N.; Mhodmonthin, A.; Wongkasemjit, S.; Jitkarnka, S. Effects of ITQ-21 and ITQ-24 as zeolite additives on the oil products obtained from the catalytic pyrolysis of waste tire. J. Anal. Appl. Pyrolysis 2009, 85, 338-344. [CrossRef]

91. Kar, Y. Catalytic pyrolysis of car tire waste using expanded perlite. Waste Manag. 2011, 31, 1772-1782. [CrossRef] [PubMed]

92. Nalluri, P.; Kumar, P.P.; Sastry, M.C. Experimental Study on Catalytic Pyrolysis of Plastic Waste Using Low Cost Catalyst; Elsevier BV: Gudlavalleru, India, 2021; Volume 45, pp. 7216-7221.

93. Chen, Z.; Wang, D.; Yang, H.; Zhang, Y.; Li, Y.; Li, C.; Yu, J.; Gao, S. Novel application of red mud as disposal catalyst for pyrolysis and gasification of coal. Carbon Resour. Convers. 2021, 4, 10-18. [CrossRef]

94. Pilusa, J.; Muzenda, E. Combustion Characteristics of Waste Tyre Pyrolysis Fuel as Industrial Burner Fuel. In Developments in Combustion Technology; Kyprianidis, K., Skvaril, J., Eds.; IntechOpen: Johannesburg, South Africa, 2016; Chapter 4.

95. Senneca, O.; Salatino, P.; Chirone, R. A fast heating-rate thermogravimetric study of the pyrolysis of scrap tyres. Fuel 1999, 78, 1575-1581. [CrossRef]

96. Rowhani, A.; Rainey, T.J. Scrap Tyre Management Pathways and Their Use as a Fuel-A Review. Energies 2016, 9, 888. [CrossRef]

97. Putra, A.E.E.; Amaliyah, N.; Syam, M.; Rahim, I. Effect of Residence Time and Chemical Activation on Pyrolysis Product from Tires Waste. J. Jpn. Inst. Energy 2019, 98, 279-284. [CrossRef] 
98. Berrueco, C.; Esperanza, E.; Mastral, F.; Ceamanos, J.; García-Bacaicoa, P. Pyrolysis of waste tyres in an atmospheric static-bed batch reactor: Analysis of the gases obtained. J. Anal. Appl. Pyrolysis 2005, 74, 245-253. [CrossRef]

99. Shah, J.; Rasul Jan, M.; Mabood, F. Catalytic pyrolysis of waste tyre rubber into hydrocarbons via base catalysts. Iran. J. Chem. Chem. Eng. 2008, 27, 103-109.

100. Chwist, M.; Gruca, M.; Pyrc, M.; Szwaja, M. By-products from thermal processing of rubber waste as fuel for the internal combustion piston engine. Combust Engines 2020, 181, 11-18. [CrossRef]

101. Quantis. Life Cycle Assessment of Plastic Energy Technology for the Chemical Recycling of Mixed Plastic Waste; Quantis: London, UK, 2020.

102. Wu, Q.; Leng, S.; Zhang, Q.; Xiao, J. Resource and environmental assessment of pyrolysis-based high-value utilization of waste passenger tires. Waste Manag. 2021, 126, 201-208. [CrossRef]

103. Appleton, T.; Colder, R.; Kingman, S.; Lowndes, I.; Read, A. Microwave technology for energy-efficient processing of waste. Appl. Energy 2005, 81, 85-113. [CrossRef]

104. Lam, S.S.; Chase, H.A. A Review on Waste to Energy Processes Using Microwave Pyrolysis. Energies 2012, 5, 4209-4232. [CrossRef]

105. Chia Yang, A.L.; Ani, F.N. Controlled microwave-induced pyrolysis of waste rubber tires. Int. J. Technol. 2016, 7, 314-322. [CrossRef]

106. Hu, J. Accelerate the Aging of Polymer as Energy-Saving Method Prior to the Pyrolysis Process; IntechOpen: Avenches, Switzerland, 2021.

107. Mohajerani, A.; Burnett, L.; Smith, J.V.; Markovski, S.; Rodwell, G.; Rahman, T.; Kurmus, H.; Mirzababaei, M.; Arulrajah, A.; Horpibulsuk, S.; et al. Recycling waste rubber tyres in construction materials and associated environmental considerations: A review. Resour. Conserv. Recycl. 2020, 155, 104679. [CrossRef]

108. Sienkiewicz, M.; Janik, H.; Borzędowska-Labuda, K.; Kucinska-Lipka, J. Environmentally friendly polymer-rubber composites obtained from waste tyres: A review. J. Clean. Prod. 2017, 147, 560-571. [CrossRef]

109. Nkosi, N.; Muzenda, E.; Mamvura, T.A.; Belaid, M.; Patel, B. The Development of a Waste Tyre Pyrolysis Production Plant Business Model for the Gauteng Region, South Africa. Processes 2020, 8, 766. [CrossRef]

110. Aylón, E.; Murillo, R.; Fernández-Colino, A.; Aranda, A.; García, T.; Callén, M.; Mastral, A. Emissions from the combustion of gas-phase products at tyre pyrolysis. J. Anal. Appl. Pyrolysis 2007, 79, 210-214. [CrossRef]

111. Undri, A.; Rosi, L.; Frediani, M.; Frediani, P. Microwave pyrolysis of polymeric materials: Waste tires treatment and characterization of the value-added products. J. Anal. Appl. Pyrolysis 2011, 103, 149-158. [CrossRef]

112. Diaz, R.; Colomines, G.; Peuvrel-Disdier, E.; Deterre, R. Thermo-mechanical recycling of rubber: Relationship between material properties and specific mechanical energy. J. Mater. Process. Technol. 2018, 252, 454-468. [CrossRef] 